\title{
Factors Associated with Low Birth Weight in Term Newborns
}

\section{Gamze Özgürhan, Serdar Cömert}

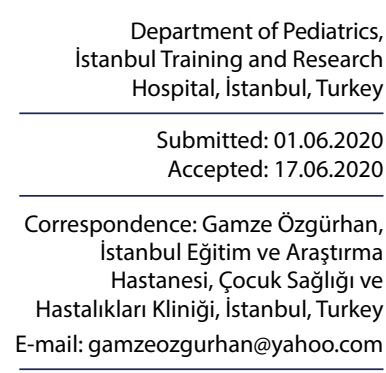

E-mail.gamzeozgurhan@yahoo.com
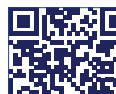

arest

Keywords: Low birth weight; newborn; maternal risk factors; smoking; socio economic risk factors.

This work is licensed under a Creative Common Attribution-NonCommercial 4.0 International License.

\begin{abstract}
Objective: Low birth weight (LBW) is a worldwide public health problem, and in emerging countries in particular. In newborns, various maternal and socio-economical factors can lead to LBW. The purpose of this study is to evaluate the risk factors associated with LBW in term newborns.
\end{abstract}

Methods: The study included 60 newborns with LBW (<2500 g) and 100 newborns with normal birth weight (2500-4000 g) as the control group. Father, mother and socio-economic factors were questioned by face-to-face interviews with mothers. Head circumference weight and height of all newborns were measured. Study and control group were compared in terms of socio-economical, neonatal, paternal and maternal factors.

Results: Average head circumference, birth height and weight in LBW group were $33.03 \pm 1.29$ $\mathrm{cm}, 47.22 \pm \mathrm{I} .72 \mathrm{~cm}$ and $2328 \pm 154.55 \mathrm{~g}$ respectively. There was no significant difference in female/male ratio between the 2 groups. Statistically significant differences were found between the 2 groups in number of antenatal care visits, smoking habits and presence of child mortalities under the age of $5(p=0.04, p=0.014$ and $p=0.033$ respectively). Socio-economic characteristics were not also found to be significantly different between the 2 groups.

Conclusion: There are variety of factors leading to LBW, some of which can be prevented by ensuring a non-smoking pregnancy and high quality and sufficient number of antenatal care visits.

\section{INTRODUCTION}

Birth weight is a key indicator of the development and growth of a fetus. It also has an important role in determining the probability of survival and physical and psychosocial development of the baby. ${ }^{[1]}$ Low birth weight (LBW), an important public health problem across the world, is an important factor affecting not only newborn mortality, but also infant and childhood morbidity. ${ }^{[2,3]}$ The World Health Organization (WHO) estimate more than 20 million newborns with LBW per year globally and that this constitutes around $15.5 \%$ of all births. More than $95 \%$ of these babies are born in under-developed countries. ${ }^{[4-6]}$

Low birth weight has been described by $\mathrm{WHO}$ as a birth weight of under $2500 \mathrm{~g}$ irrespective of gestational age. ${ }^{[7]}$ Birth weight specific infant mortality increases below this value. ${ }^{[3,8]}$ Infants with LBW bear 40 times more risk of mortality in the first 4 weeks' of life versus infants with normal weight. ${ }^{[2]}$

Development of fetus is dependent on a number of factors including the genetic nature of the fetus, adequate placental supply to fetus and hormonal and various growth factors. It has also been argued that there may be variances in fetal growth and birth weight based on ethnicity and geographical area. ${ }^{[9]}$ Factors leading to LBW in different societies should be studied to take necessary actions to prevent LBW. In this study, we aim to assess risk factors associated with LBW in our local patient population by making a comparison between term newborns in our hospital with LBW and those with normal birth weight.

\section{MATERIALS AND METHODS}

This prospective and comparative study was conducted according to the Helsinki Declaration Principles and was confirmed by the local ethics committee. All participants were informed verbally and in writing about the study and their written consent were obtained.

The World Health Organization defines under-2500 g newborns as LBW infants, between 2500 and $4000 \mathrm{~g}$ as normal birth weight infants, and above $4000 \mathrm{~g}$ as infants with macrosomia. Newborns had been divided into 2 groups according to birth weight, a group that consists of LBW newborns (<2500 g) and a control group including normal birth weight newborns (2500-4000 g). Control and study group were compared in terms of socio-economical, maternal and neonatal factors. 
Subjects were born in same hospital and socio-culturally were from middle class families. Subjects were selected from among newborns at their 38-42 gestational weeks. Exclusion criteria included preterm births ( $<38$ weeks) and multiple births. All newborns underwent a comprehensive physical examination, including a weight, height and head circumference.

Data collection was done using face-to-face interviews, where a structured and pretested questionnaire, including mother's age, education, occupation, marital status, parity, birth interval, health history, weight gain in pregnancy, smoking habits, number of antenatal care visits, hemoglobin level before delivery and iron and folic acid intake during pregnancy, and whether or not there were any child mortalities under the age of 5 in the past due to a medical condition and if yes, how many. Also included were father's age, education and occupation, as well as socio-economical indicators such as the existence of social security, monthly household income and number of inhabitants at home.

\section{Data analysis}

In this study, the Statistical Package for Social Sciences (SPSS) was done using version 20.0 (SPSS, Chicago, IL). The distribution characteristics of variables were evaluated with the I-sample Kolmogorov-Smirnov test. In comparison of the clinical and demographic characteristics of LBW and control groups, $X^{2}$ test was used for categorical variables and Mann-Whitney $U$ test was used for continuous variables. $P<0.05$ was accepted statistically significant.

\section{RESULTS}

This study included 160 newborns in total: 60 newborns in the LBW group and 100 newborns in the control group.

Female/male ratio of the newborns with LBW included in this study was $2 / I$ and there was no significant difference in this rate between LBW group and control group $(p=0.09)$.

In LBW group; means head circumference, birth weight and height were $33.03 \pm 1.29 \mathrm{~cm}, 2328 \pm 154.55 \mathrm{~g}$ and $47.22 \pm 1.72 \mathrm{~cm}$ respectively (Table I).

Regarding maternal characteristics, there were not any sta-

Table I. The demographic and clinical characteristics of LBW and control groups

\begin{tabular}{|c|c|c|c|}
\hline \multirow[b]{2}{*}{ Characteristics } & \multicolumn{2}{|c|}{ Mean \pm SD } & \multirow[b]{2}{*}{$\mathbf{p}$} \\
\hline & $\begin{array}{l}\text { LBW group } \\
(n=60)\end{array}$ & $\begin{array}{l}\text { Control } \\
\text { group } \\
(n=100)\end{array}$ & \\
\hline Gender (male/female) & $21 / 39$ & $47 / 53$ & 0.09 \\
\hline Height $(\mathrm{cm})$ & $47.22 \pm 1.72$ & $50.2 \pm 1.44$ & - \\
\hline Weight (cm) & $2328 \pm 154.55$ & $3336.4 \pm 337.7$ & - \\
\hline Head circumference $(\mathrm{cm})$ & $33.03 \pm 1.29$ & $34.9 \pm 0.8$ & - \\
\hline
\end{tabular}

SD: Standard deviation; LBW: Low birth weight; *Statistically significant increased values $(p<0.05)$. tistically significant differences in terms of age, education, occupation, marital status, parity, birth interval, health history, hemoglobin level before delivery, iron and folic acid intake during pregnancy between two groups. However, statistically significant differences were found between the 2 groups in maternal smoking, presence of child mortality under the age of 5 and number of antenatal care visits. The maternal clinical and demographic characteristics of groups are shown in Table 2.

When it comes to paternal characteristics, age, education and occupation, any statistically significant differences were not found between two groups.

No significant differences were found regarding socio-economic characteristics between two groups (Table 2).

\section{DISCUSSION}

Birth weight has been identified as both a good indicator of fetus health, an important determinant of neonatal mortality and morbidity and one of the important drivers behind growth in childhood and adolescence. ${ }^{[10]}$ Fetal growth and birth weight differ from country to country, and even from region to region in the same country. ${ }^{[4, I]}$ In developed countries, the most important factor affecting fetus growth has been mother's smoking habit; whereas in developing countries the leading factors have been associated with maternal diet and infections. ${ }^{[12,13]}$ Therefore, it is crucial to collect information on LBW and any factors leading to it in different parts of the world as this would provide key insights to creating solutions to the problem at hand.

Many factors affecting birth weight have been defined, and these can be classified as fetal, placental and maternal risk factors. ${ }^{\left[{ }^{[9]}\right.}$ Although many studies have suggested a correlation between mother's age and LBW, some others have failed to do so. Studies by Shin et al. ${ }^{[3]}$ and Hosain et al. ${ }^{[6]}$ have been among those that suggest a strong correlation, with newborns from older mothers having higher birth weight. ${ }^{[3,6]}$ On the contrary, our study does not suggest a statistically significant relationship between mother's age and LBW. In line with our study, Biswas et al. ${ }^{[14]}$ argue that there is no association between LBW and factors such as mother's age, literacy, and occupation. ${ }^{[14]}$

In many studies, it has been shown that there is an inverse correlation between fetus growth and mother's smoking behavior. Moreover, smoking has been identified as the factor with the highest negative impact on fetal growth in developed countries. ${ }^{[12]}$ In our study, we identified a strong correlation between maternal smoking and LBW. Newborns by smoking mothers bear 3-4.5 times more risk of LBW when compared to newborns by non-smoking mothers.

Every year, 10 million children under the age of 5 die globally. ${ }^{[15]}$ Forty percent of these deaths occur within the first month of life, and $30 \%$ within the first week. According to $\mathrm{WHO}, 54 \%$ of child deaths under the age of 5 are due to malnutrition, and this has been a crucial health issue in 
Table 2. Maternal and socio-economical characteristics of LBW and control groups

\begin{tabular}{|c|c|c|c|}
\hline Characteristics & $\begin{array}{l}\text { LBW group } \\
\quad(n=60)\end{array}$ & $\begin{array}{l}\text { Control group } \\
(n=100)\end{array}$ & $\mathbf{p}$ \\
\hline \multicolumn{4}{|l|}{ Education, $\mathrm{n}(\%)$} \\
\hline Illeterate & $4(6.7)$ & $4(4)$ & NS \\
\hline Primary school & $34(56.7)$ & $56(56)$ & \\
\hline Secondary school & $10(16.7)$ & $19(19)$ & \\
\hline High school & $9(15)$ & $15(15)$ & \\
\hline University & $3(5)$ & $6(6)$ & \\
\hline Occupied, n (\%) & $13(2 \mid .7)$ & $13(13)$ & NS \\
\hline Married, n (\%) & $56(93.3)$ & $97(97)$ & NS \\
\hline \multicolumn{4}{|l|}{ Parity, n (\%) } \\
\hline 1 & $26(43.3)$ & $24(24)$ & NS \\
\hline 2 & $13(21.7)$ & $45(45)$ & \\
\hline 3 & $13(2 \mid .7)$ & $2 I(2 I)$ & \\
\hline 4 & $6(10)$ & $8(8)$ & \\
\hline$\geq 5$ & $2(3.3)$ & $2(2)$ & \\
\hline Disease during pregnancy, n (\%) & $15(25)$ & $27(27)$ & NS \\
\hline Maternal disease, n (\%) & $5(8.3)$ & $16(16)$ & NS \\
\hline Smoking, n (\%) & $15(25)$ & $10(10)$ & $0.01 *$ \\
\hline \multicolumn{4}{|l|}{ Antenatal care visits, $\mathrm{n}(\%)$} \\
\hline$<3$ & $9(15)$ & $6(6)$ & $0.04 *$ \\
\hline$>3$ & $51(85)$ & $94(94)$ & \\
\hline \multicolumn{4}{|l|}{ Iron intake, n (\%) } \\
\hline None & $13(21.7)$ & $13(13)$ & NS \\
\hline Regular & $36(60)$ & $65(65)$ & \\
\hline Irregular & II (I8.3) & $22(22)$ & \\
\hline \multicolumn{4}{|l|}{ Folic acid intake, n (\%) } \\
\hline None & $36(60)$ & $58(58)$ & \\
\hline Regular & $21(35)$ & $34(34)$ & \\
\hline Irregular & $3(5)$ & $8(8)$ & \\
\hline Child mortality (under age of 5), n (\%) & $8(13.3)$ & $4(4)$ & $0.03 *$ \\
\hline Age (years) (mean $\pm S D)$ & $28.45 \pm 6.69$ & $28.2 \pm 5.16$ & NS \\
\hline Weight gain $(g)($ mean $\pm S D)$ & $1|666.6 \pm 48| 7.5$ & $12260 \pm 5 \mid 35.2$ & NS \\
\hline Hemoglobin level (g/dL) (mean $\pm S D)$ & $11.98 \pm 1.5$ & $11.9 \pm 1.4$ & NS \\
\hline Social security, n (\%) & $52(86.7)$ & $86(86)$ & NS \\
\hline \multicolumn{4}{|l|}{ Monthly income (Turkish Liras) } \\
\hline$<1000$ & $7(11.7)$ & II (II) & \\
\hline $1000-2000$ & $41(68.3)$ & 7I (7I) & \\
\hline $2000-4000$ & $7(11.7)$ & II (II) & NS \\
\hline$>4000$ & $5(8.3)$ & $7(7)$ & \\
\hline Number of inhabitants at home (mean $\pm S D)$ & $4.95 \pm 2.7$ & $4.9 \pm 2.1$ & NS \\
\hline
\end{tabular}

LBW: Low birth weight; SD: Standard deviation; *Statistically significant increased values $(p<0.05)$; NS: Non-significant.

emerging countries in particular. ${ }^{[16]}$ In our study, we found that LBW was more common in babies whose mothers had previously lost an under 5 years old child due to a medical condition $(p<0.05)$. Considering adequate food supply from the placenta to the baby is one of the most important factors for fetus growth, it would be a fair conclusion to say that lack of adequate food supply before birth may be one of the most important reasons of early infant mortality, particularly in neonatal period.

Many studies have highlighted the relationship between
LBW and mother's smoking habit, education, age, inadequate weight gain and any infections during pregnancy and insufficient antenatal care visits. ${ }^{[17]}$ Socio-economical factors have been identified as having a high degree of association with LBW, and among these socio-economical factors, number of maternal care visits during pregnancy is found to be a particularly important one. ${ }^{[17,18]}$ In parallel to these findings, we also determined a statistically significant correlation between low numbers of antenatal care visits and LBW. What is also important regarding antenatal care 
visits is the quality of service during these visits, which is pointed out in some studies where the rate of improvement in morbidity and mortality is not at the expected level in the face of increased numbers of antenatal visits. [18,19] Therefore, a sufficient number of antenatal care visits with a high quality service level is of utmost importance as a preventive method against LBW.

A key limitation of our study is the relatively small sample size; however, this limitation is mainly due to our decision to exclude any pre-term newborns and focus only on term newborns, eliminating any bias and noise factors due to pre-term newborns that may have led to false conclusions.

\section{CONCLUSION}

Many factors can lead to LBW development. However, improving maternal general health conditions, cessation of smoking during pregnancy and providing sufficient and qualified antenatal care visits are the key issues for prevention of LBW.

\section{Ethics Committee Approval}

Bağcılar Training and Research Hospital Non-interventional Clinical Research Ethics Committee (protocol no: 2016/445, date: 17.03.2016).

Peer-review

Internally peer-reviewed.

Authorship Contributions

Concept: G.O., S.C.; Design: G.O., S.C.; Supervision: G.O., S.C.; Materials: G.O.; Data: G.O.; Analysis: G.O., S.C.; Literature search: G.O., S.C.; Writing: G.O., S.C.; Critical revsion: G.O., S.C.

Conflict of Interest

None declared.

\section{REFERENCES}

1. Metgud CS, Naik VA, Mallapur MD. Factors affecting birth weight of a newborn-a community based study in rural Karnataka, India. PLoS One 2012;7:e40040. [CrossRef]

2. Goldenberg RL, Culhane JF. Low birth weight in the United States. Am J Clin Nutr. 2007;85:584S-90S. [CrossRef]
3. Shin SM, Chang YP, Lee ES, Lee YA, Son DW, Kim MH, et al. Low birth weight,very low birth weight rates and gestational age-specific birth weight distribution of korean newborn infants. J Korean Med Sci 2005;20:182-7. [CrossRef]

4. United Nations Children's Fund and World Health Organization. Low birth weight: Country, regional and global estimates. New York: UNICEF; 2004.

5. Alexander GR, Kogan MD, Himes JH. 1994-1996 U.S. singleton birth weight percentiles for gestational age by race, Hispanic origin, and gender. Matern Child Health J 1999;3:225-31. [CrossRef]

6. Hosain GM, Chatterjee N, Begum A, Saha SC. Factors associated with low birthweight in rural Bangladesh. J Trop Pediatr 2006;52:87-91.

7. World Health Organization. Preterm birth. Fact sheet No 363. Available at: https://www.who.int/news-room/fact-sheets/detail/preterm-birth Accessed Aug 25, 2020.

8. Spector JM, Daga S. Preventing those so-called stillbirths. Bull World Health Organ 2008;86:315-6. [CrossRef]

9. Taeusch HW, Ballard RA, Gleason CA. Avery's Diseases of the Newborn. 8th Ed. Philadelphia: Elsevier Saunders; 2005. p. 32-3.

10. Mendes CQ, Cacella BC, Mandetta MA, Balieiro MM. Low birth weight in a municipality in the southeast region of Brazil. Rev Bras Enferm 2015;68:1169-75. English, Portuguese. [CrossRef]

11. Fuchs GJ. Low Birth Weight. Global forum for Health ResearchAnnual Report10/90. Available at: www.globalforumhealth.org. Accessed March 28, 2005.

12. Kramer MS, Séguin L, Lydon J, Goulet L. Socio-economic disparities in pregnancy outcome: why do the poor fare so poorly? Paediatr Perinat Epidemiol 2000;14:194-210. [CrossRef]

13. Robinson JS, Moore VM, Owens JA, McMillen IC. Origins of fetal growth restriction. Eur J Obstet Gynecol Reprod Biol 2000;92:13-9.

14. Biswas R, Dasgupta A, Sinha RN, Chaudhuri RN. An epidemiological study of low birth weight newborns in the district of Puruliya, West Bengal. Indian J Public Health 2008;52:65-71.

15. Kliegman RM, Behrman RE, Jenson HB, Stanton BF. Nelson Textbook of Pediatrics. 18th ed. Philadelphia: Saunders Elsevier; 2008. p. 2-4.

16. Bryce J, Boschi-Pinto C, Shibuya K, Black RE, WHO Child Health Epidemiology Reference Group. WHO estimates of the causes of death in children. Lancet 2005;365:1147-52. [CrossRef]

17. Nazari M, Zainiyah SY, Lye MS, Zalilah MS, Heidarzadeh M. Comparison of maternal characteristics in low birth weight and normal birth weight infants. East Mediterr Health J 2013;19:775-81. [CrossRef]

18. Silva AA, Silva LM, Barbieri MA, Bettiol H, Carvalho LM, Ribeiro VS, et al. The epidemiologic paradox of low birth weight in Brazil. Rev Saude Publica 2010;44:767-75. [CrossRef]

19. Akin Y, Cömert S, Turan C, Unal O, Piçak A, Ger L, et al. Increasing low birth weight rates: deliveries in a tertiary hospital in istanbul. Iran J Pediatr 2010;20:284-90

\section{Term Yenidoğanlarda Düşük Doğum Ağırlığına Etki Eden Faktörlerin Değerlendirilmesi}

Amaç: Düşük doğum ağılığı (DDA), tüm dünyada ve özellikle gelişmekte olan ülkelerde bir halk sağlığı sorunudur. Çeşitli maternal ve sosyoekonomik faktörler yenidoğanlarda DDA'ya yol açabilir. Bu çalışmanın amacı term yenidoğanlarda, DDA ile ilişkili risk faktörlerini değerlendirmektir.

Gereç ve Yöntem: Çalışmaya hastanemizde doğan DDA’lı (<2500 g) 60 yenidoğan ve kontrol grubu olarak normal doğum ağırlığına (2500-4000 g) sahip 100 yenidoğan dahil edildi. Annelerle yüz yüze görüşülerek; anne, baba ve sosyoekonomik faktörler üzerine sorular içeren bir anket uygulandı. Tüm yenidoğanların ağılık, boy ve baş çevresi kaydedildi. Toplanan verilere göre bu iki grup; yenidoğan, maternal, paternal ve sosyoekonomik faktörler açısından karşılaştırıldı.

Bulgular: Çalışma grubunda ortalama doğum ağılığı, boy ve baş çevresi sırasıyla $2328 \pm 154.55 \mathrm{~g}, 47.22 \pm 1.72 \mathrm{~cm}$ ve $33.03 \pm 1.29 \mathrm{~cm}$ idi. Çalışma grubu ile kontrol grubu arasında kadın/erkek oranında istatistiksel olarak anlamlı bir fark yoktu. Sigara içme alışkanlıklarında, doğum öncesi bakım ziyaretlerinde ve 5 yaşın altındaki çocuk ölümlerinin varlığında iki grup arasında istatistiksel olarak anlamlı farklılık gözlendi (sırasıyla, $\mathrm{p}=0.014, \mathrm{p}=0.04$ ve $\mathrm{p}=0.033$ ). Sosyoekonomik özellikler açısından iki grup arasında istatistiksel olarak anlamlı farklılık bulunmadı.

Sonuç: Düşük doğum ağırlığına yol açan birçok faktör vardır. Bu faktörler arasında yer alan sigara kullanımının engellenmesi ve anneye doğum öncesi kaliteli ve yeterli sayıda bakım hizmeti sunmak önlenebilir faktörlerdendir.

Anahtar Sözcükler: Düşük doğum ağırlığ; maternal risk faktörleri; sigara kullanımı; sosyoekonomik risk faktörleri; yenidoğan. 